\title{
DESCRIPTIONS AND BIOLOGICAL NOTES OF IMMATURES OF MICROCTENOCHIRA DIFFICILIS (COLEOPTERA, CHRYSOMELIDAE, HISPINAE, CASSIDINI)
}

\author{
Édson Possidônio Teixeira' ${ }^{1}$ \\ Sônia A. Casari
}

\begin{abstract}
Descriptions and illustrations of egg, larva and pupa of Microctenochira difficilis (Boheman, 1855) are presented for the first time. Biological notes and bionomic informations are also included. Eggs, larvae, pupae and adults were collected on Tabebuia sp. (Bignoniaceae) in Monjolinho arboretum at Centro Experimental Santa Elisa, Campinas, State of São Paulo, and kept in laboratory for rearing.
\end{abstract}

KEYWORDS. Bionomics, larva, ootheca, pupa, Tabebuia.

\section{INTRODUCTION}

Chapuis (1875) erected Ctenochira from Coptocycla (pars) Boheman and included it into the "Groupe XVII. Aspidimorphites". SPAETH (1926), treating of the genus Ctenochira (type species, Coptocycla aciculata Boheman, 1855) in the monography of the American Cassidinae, established Microctenochira, new subgenus (type species, Coptocycla jousselini Boheman, 1855). He divided the 99 species of the genus in six groups, including C. difficilis Boheman, 1855 in the 6th group, composed by six species. HincKs (1950) verified that Ctenochira was preoccupied by the senior homonym of Foerster, 1855 (Hymenoptera, Ichneumonidae); also raised the subgeneric name Microctenochira to genus, applied it for the typical subgenus and established Euctenochira, new subgeneric name for the section previously called Ctenochira sensu stricto by Spaeth. HincKs (1952), treating of the Cassidinae genera, applied the new names and catalogued Microctenochira with the subgenus Euctenochira Hincks, 1950. BorOwIEC (1995) presented the historical review and the results of the phylogenetic studies of Cassidinae. He divided the subfamily in four groups and included Cassidini into the "Cassida group". According to him, "each group is monophyletic, but phylogenetic relationships between these groups are very difficult to reconstruct because of uniform habitus with many mosaic homoplasies and the lack of biological data for most genera". BOROwIEC (1995) considered Cassidini as a tribe of Hispinae, position followed by LAwrenCE \& Newton (1995). Borowiec (1996),

1. Instituto Agronômico de Campinas, Caixa Postal 28, 13001-970, Campinas, SP, Brazil. (edson@cec.iac.br)

2. Museu de Zoologia, Universidade de São Paulo, Caixa Postal 42594, 04299-970, São Paulo, SP, Brasil. Fellowship CNPq. (casari@usp.br). 
treating of the Neotropical Cassidinae, used the generic name Microctenochira. BuzzI (1999) misinterpreted HINCKS (1950) paper and considered Euctenochira as a valid generic name. BlACKWELDER (1946) catalogued 114 species to "Ctenochira". According to ŚWIETOJAŃSKA \& BOROWIEC (1999), last catalogue lists 104 species in Microctenochira.

Up to now, immatures of Microctenochira were unknown. Eggs, larvae, pupae and adults of $M$. difficilis were collected feeding on leaves of Tabebuia sp. (ipê) (Bignoniaceae), in Monjolinho arboretum at Centro Experimental Santa Elisa, Instituto Agronômico de Campinas, São Paulo State, and reared in laboratory. The immatures are illustrated and described, and bionomic informations are also included. The terminology of the sense organs follows RościszeWSKA $(1980,1981)$.

Larvae of "Cassidinae" are characterized especially by presenting body flattened, usually ovate, slightly sclerotized, without tubercles; thoracic and abdominal segments usually with lateral process; caudal forks usually present, may carry faeces and exuviae or only the exuviae; head hypognathous; labrum free; antenae 2-segmented (Воотн et al., 1990).

\section{Microctenochira difficilis (Boheman, 1855)}

(Figs. 1-21)

Eggs and ootheca. Eggs oblong, yellowish-white, not sculptured, each fixed to lamella by basal filamentous stalk. Ootheca (figs. 1,21) formed by several sclerotized castaneus lamellae bearing variable number of eggs, disposed in layers.

Larva. Length: 1.3-6.5 mm (variable instar). Cyphosomatic (figs. 2, 3). Greenish-yellow with head, pronotum and sides of meso- and metanotum, abdominal segments and legs black; after fixation, cream with head brown and pronotum (except lateroanterior band) and lateral fourth of meso- and metanotum brownish. Integument slightly sclerotized, asperate in some areas, more concentrate laterally; in high magnification representing micro-sclerotized rings (fig. 6); many stout short dispersed setae. Thoracic and abdominal segments bearing lateral scoli with asperites and stout short setae inserted in sclerotized punctures (fig. 6).

Head (figs. 7, 12) hypognathous, rounded, moderately sclerotized; epicranial stem long; endocarina extending from epicranial stem to frontoclypeal suture; frontal arms short and V-shaped; labrum free, clipeolabral suture complete. Each side of head with five stemmata on darker spot (fig. 7): one anterior, lateroexternal to antenna and a group of four behind it. Antenna (figs. 8, 9) very small, 2-segmented; basal segment transverse, bearing two ventral cupolae near anterior margin; distal segment bearing at apex one well developed membranous conical sensory appendix and five stout setae. Clypeus (fig. 13) transverse, translucent on anterior half, bearing four setae near basal margin. Labrum (fig. 13) transverse, semielliptical, bearing two cupolae and two setae near base, two cupolae near middle, two lateromedially setae on each side and a row of seven stout setae near distal margin. Epipharynx (fig. 14) medially covered with setae of variable sizes; each side with three stout long setae lateroanteriorly and one short seta, two cupolae and a papilla plate near middle; one sclerite near each lateral margin. Mandible (figs. 10,11) palmate and 5-toothed. Maxilla (fig. 16): stipites elongate, membranous, sclerotized laterointernally, bearing three setae; cardo indistinct, mala (fig. 15) bearing nine stout setae; palpifer partially membranous bearing three setae and two cupolae; maxillary palp 2-segmented; basal segment bearing three setae (one broken in fig. 15); distal segment bearing near apex one median sized peg on each side, one cupola ventral and numerous sense papillae 

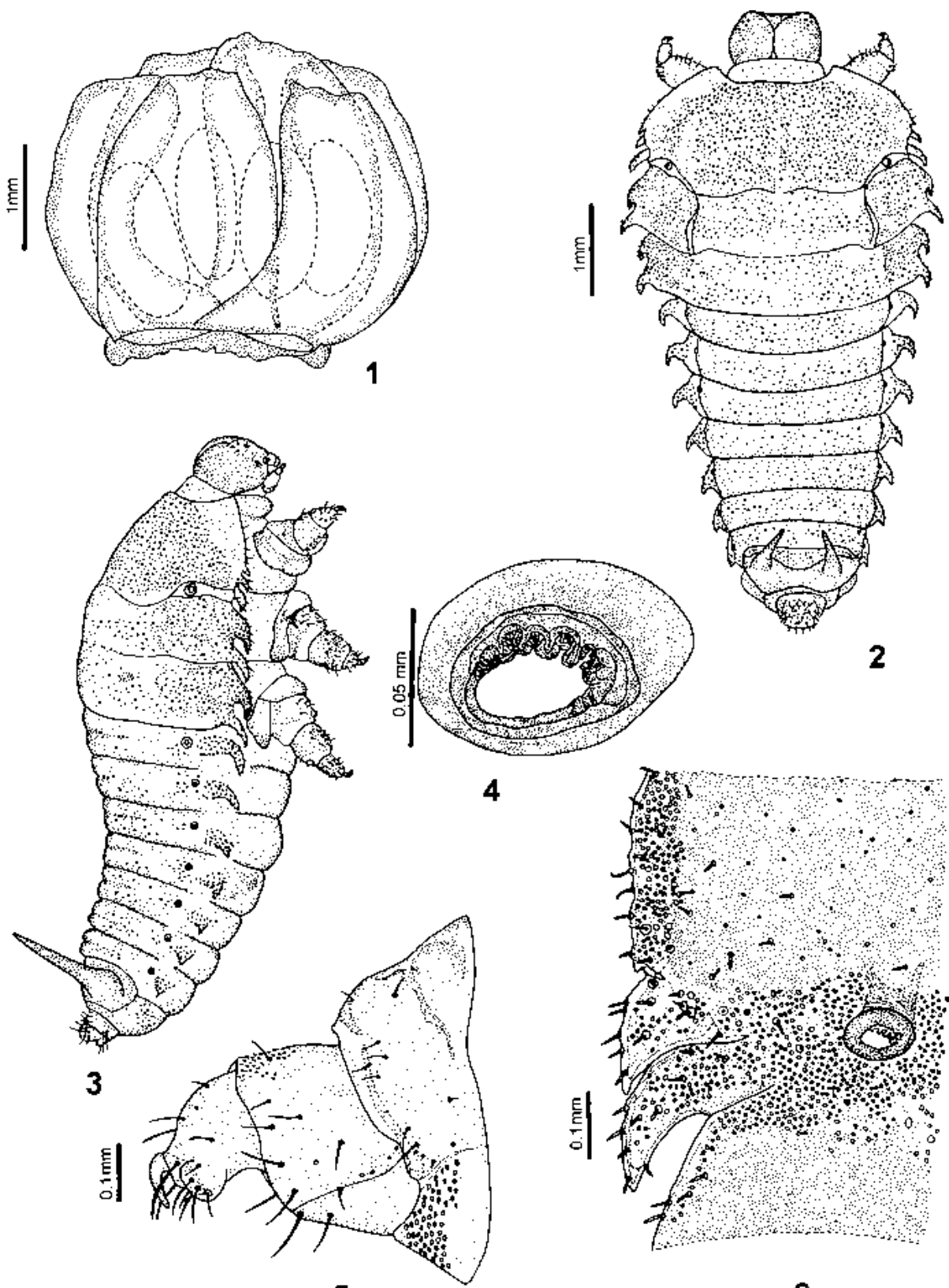

5

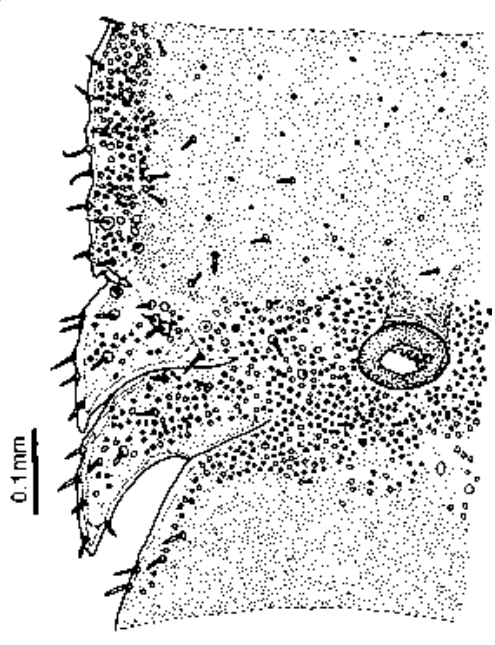

6

Figs. 1-6. Microctenochira difficilis: 1, ootheca; larva: 2, dorsal; 3, lateral; 4, thoracic spiracle; 5, leg; 6 , lateral margin of thorax. Figs. 2, 3, to same scale. 


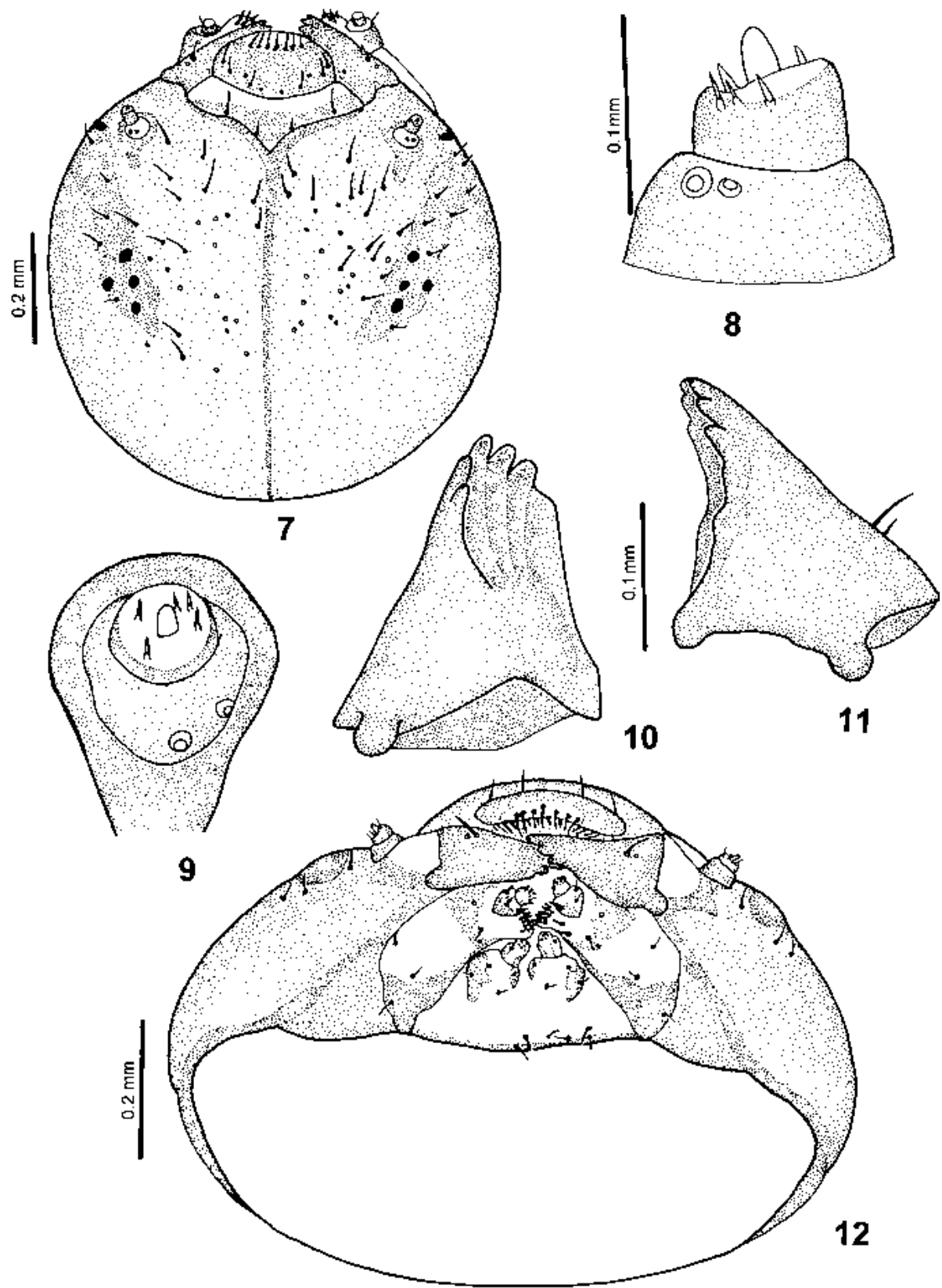

Figs. 7-12. Microctenochira difficilis, larva: 7, 12, head, dorsal, ventral; 8, 9, left antenna, ventral, from above; 10, 11, mandible, ventrolateral, ventral. Figs. 8,$9 ; 10,11$ to same scale. 


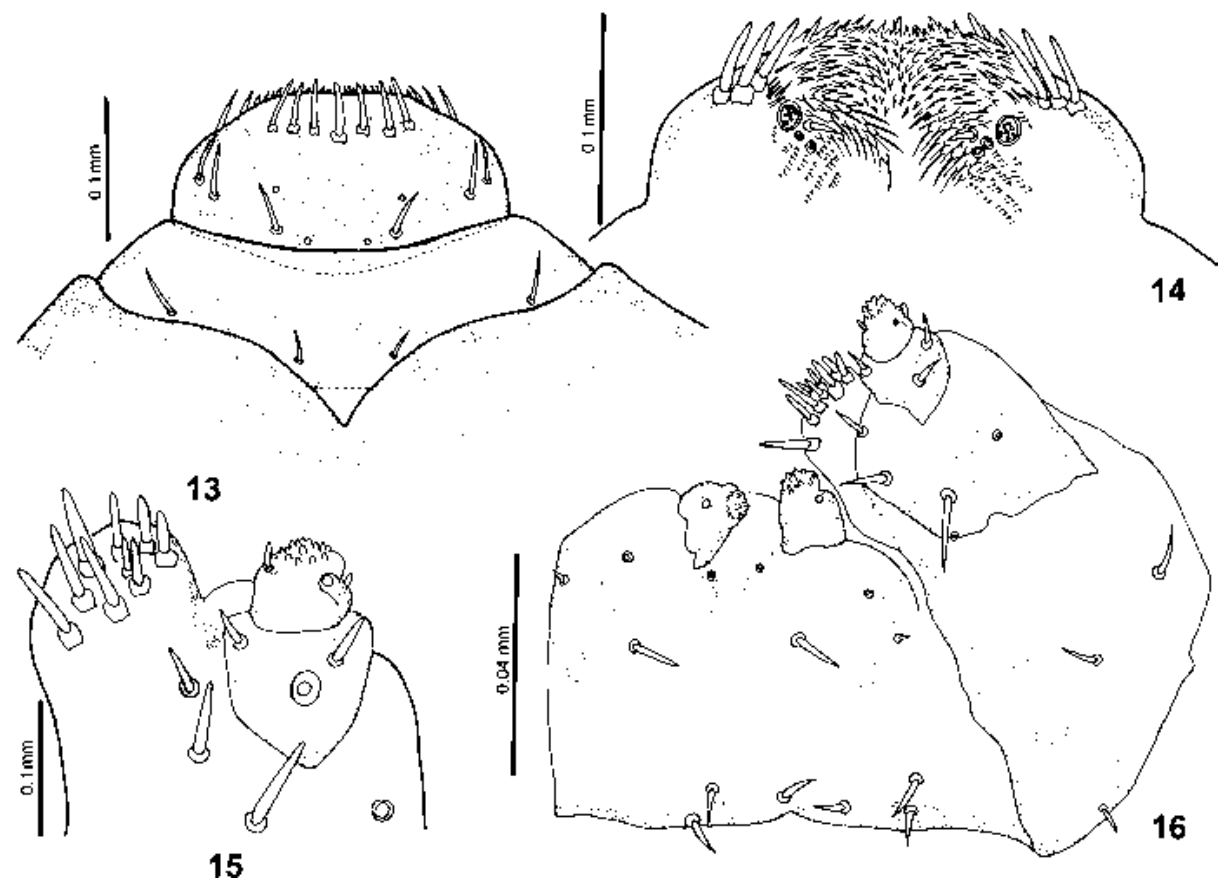

Figs. 13-16. Microctenochira difficilis, larva: 13, clypeus and labrum; 14, epipharynx; 15, mala and maxillar palp, ventral; 16, maxilla and labium, ventral.

at apex. Labium (fig. 16) almost totally membranous bearing two setae near middle and six near base; palpiger partially membranous bearing one small peg and two cupolae; labial palpi 1-segmented with one lateroexternal cupola near apex and numerous apical sense bouquets (median larger).

Thorax (figs. 2,3) wider than abdomen; pronotum slightly shorter than meso- and metanotum together, narrowed anteriad; each side bearing three asperate scoli (first smaller). Each side of meso- and metanotum with two lateral asperate scoli each one. One large annular spiracle (fig. 4) on intersegmentar area between pro- and mesonotum. Leg (fig. 5) stout; coxa ring-shaped, membranous ventrally and bearing several short setae lateral- and dorsally; trochanter triangular with three setae; femur elongate, asperate dorsoanteriorly and bearing several short setae; tibiae narrower, elongate, bearing several setae concentrate in lateroanterior external lobe; tarsunguli sclerotized and curved.

Abdominal segments 1-7 band-like, bearing each side one lateral rugous scolus and one dorsal annular spiracle (first larger); segment 8 bearing paired dorsal forked process; segments 9-10 placed beneath segment 8 ; segment 9 reduced, ring-like; segment 10 tubular, bearing several short setae.

Pupa (figs. 17-20). Length: 5-6 mm. Cream with lateral and median patches on pronotum, two small patches and median small grooves on mesonotum, almost whole metanotum and tergites 1-7 (except spiracular area and lateral processes), brownish. Integument covered with micro-sclerotized rings (fig. 20) giving asperate appearance. 

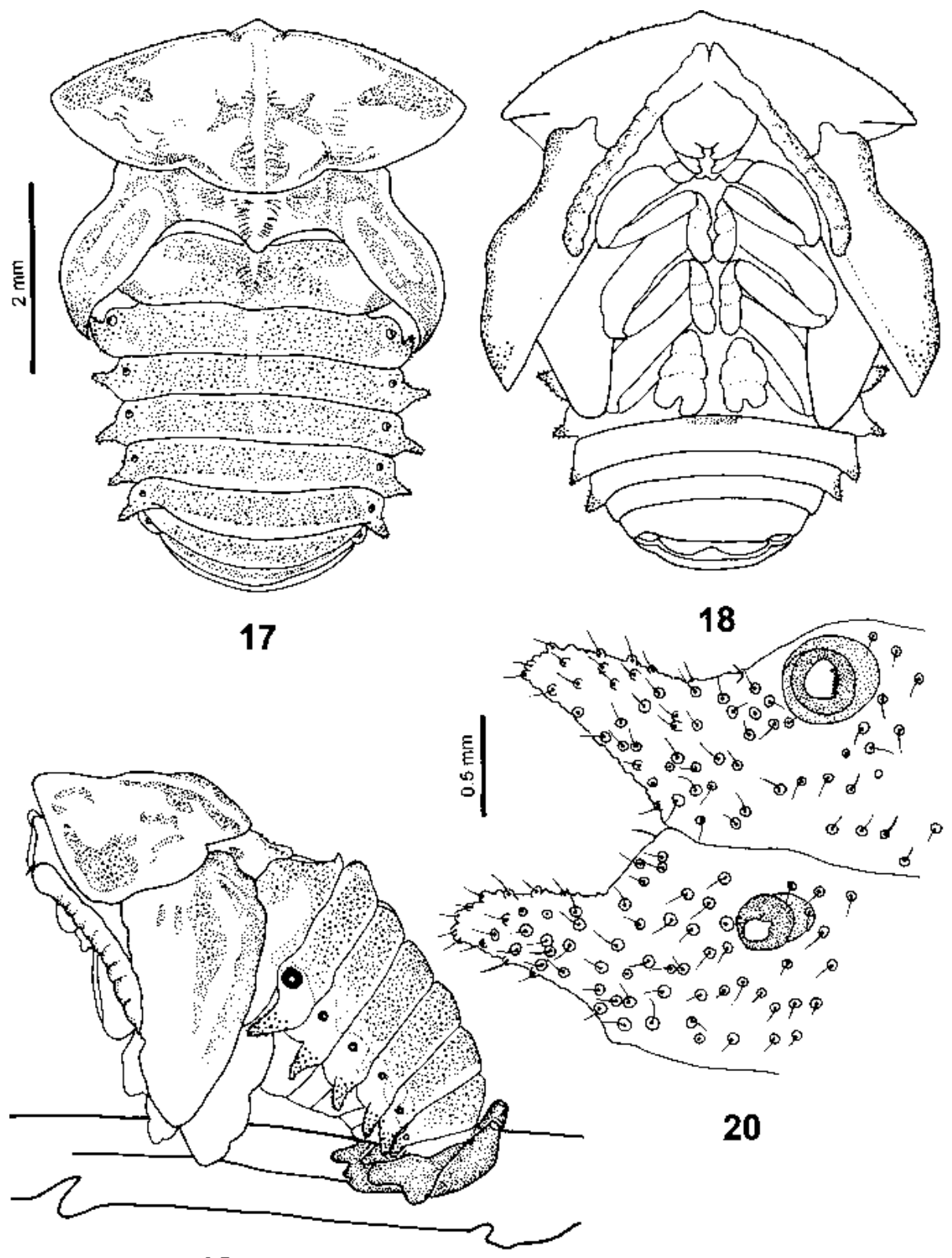

19

Figs. 17-20. Microctenochira difficilis, pupa: 17, dorsal; 18, ventral; 19, lateral; 20, lateral margin of abdomen. Figs. 17-19 to same scale. 


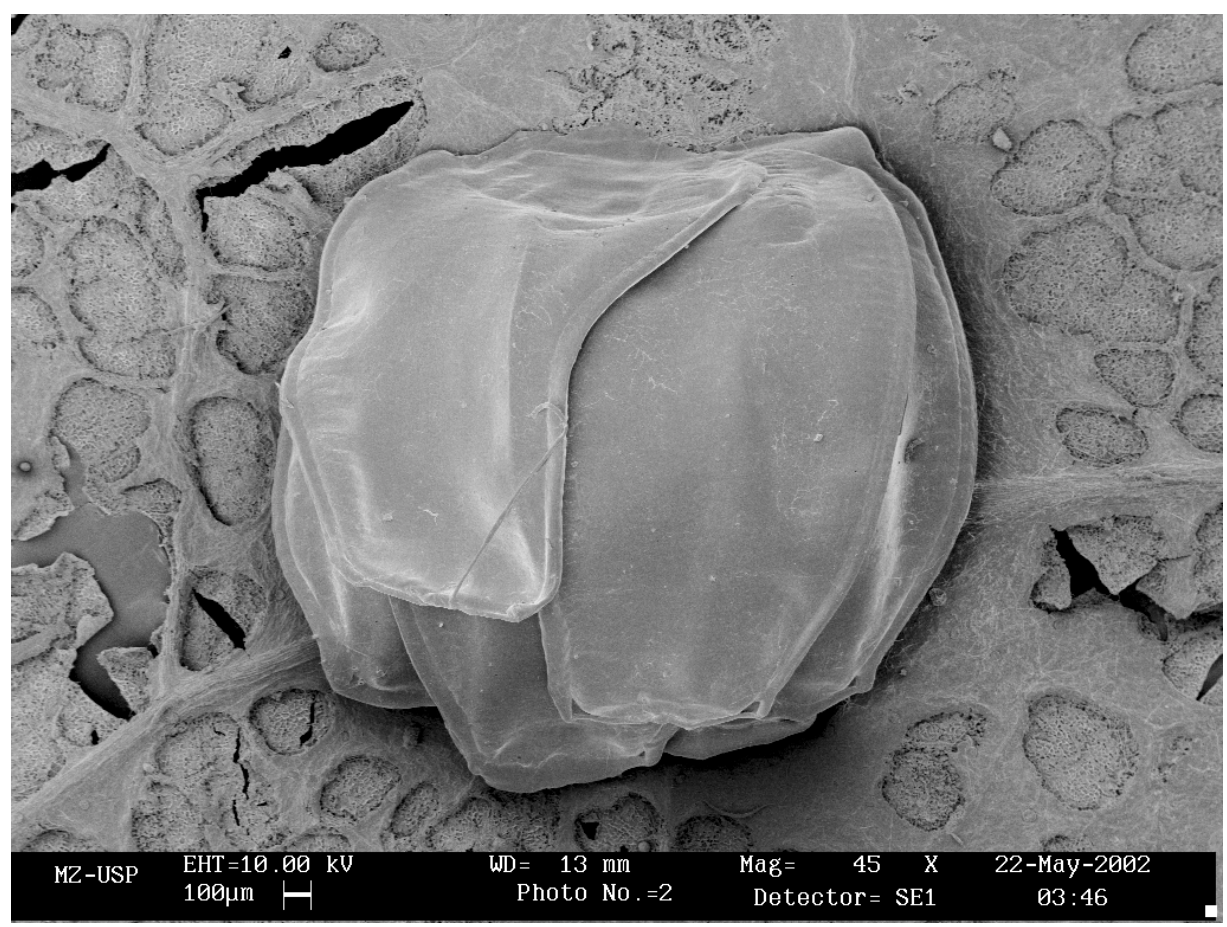

Fig. 21. Microctenochira difficilis, ootheca.

Head hypognathous, not visible from above; theca antennal brownish and asperate near external borders. Pronotum transverse, prominent on anterior median region; posterior margin trilobed; slightly concave near lateroposterior margin; more visibly asperate on darker areas and at margins. Mesonotum prominent mediobasally, with two concavities near anterior margin and two rows of inclined short grooves near middle; theca alar with longitudinal brown bands intercalated by cream; brown bands visibly asperate. Metanotum upwards mediobasally, visibly asperate on darker areas. Abdominal segments 1-6 with one lateral rugous scolus on each side. Each segment with one pair of dorsolateral annular spiracle (first larger), 1st segment upwards dorsomedially. An elliptical brownish spot at middle of anterior margin of 4 th sternite.

Material examined. BRAZIL, São Paulo: Campinas (Fazenda Santa Elisa, Monjolinho), 21.III.2001, J. E. A. Bertoni col., 3 larvae of first instar, 1 mature larva, 8 adults and 4 oothecae fixed; 22.III.2002, E. P. Teixeira \& J. E. Bertoni col., 17 mature larvae reared to adult, 1 pupa reared to adult, and 14 adults newly emerged, and 4 oothecae, 3 pupae, 5 larvae and 9 adults fixed; 03.V.2002, E. P. Teixeira col., 5 oothecae entire and 19 destroyed, 18 larvae, 7 pupae and 2 adults fixed. All the material is in Museu de Zoologia, São Paulo (MZSP), except 22 adults, in Instituto Agronômico de Campinas, Campinas (IACC 7436).

Biological notes. The larvae of Microctenochira difficilis were found feeding on leaves of Tabebuia sp. (Bignoniaceae) located near a swampy area. The oviposition takes place on both sides of the leaves, near the margins. Eggs are laid in clusters of variable 
number, each one protected by sclerotized lamella forming the ootheca (fig. 21). It was found from 6-10 lamellae each ootheca (11 oothecae observed) and one ootheca each leaf, more frequent on inferior face. The pupation takes place on both faces.

During feeding, the larvae scrape the leaf limb, and the veins and rib stay intact, lace-like. Larvae, and usually pupae, support the exuvio-fecal anex on forked dorsal process of segment 8. This exuvio-fecal anex, called "parasol", is used as protection and covers almost completely the body. When the larva is disturbed, the "parasol" is imediately moved up- and forewards.

In laboratory, eggs and larvae were placed in glass containers $(13,3 \mathrm{~mm} \times 20,1 \mathrm{~mm})$ at room temperature. None larva emerged from collected oothecae, but some collected larvae pupate. The prepupal period lasted about three days and the pupal from 4-14 days. The longevity of the collected newly emerged adults, at about $25^{\circ} \mathrm{C}$, without food, was about 20 days. This species overlaps generations and presents a gregarious behaviour.

Acknowledgments. To José Eduardo de Arruda Bertoni (IACC), who brought the first material of Microctenochira and identified the botanical species, Carlos Campaner (MZSP) for identification of Cassidini and Ubirajara R. Martins (MZSP) for helping in nomenclatural problems.

\section{REFERENCES}

Blackwelder, R. E. 1946. Checklist of the coleopterous insects of Mexico, Central America, the West Indies, and South America. Bull. U. S. natn. Mus., Washington, 185(4):551-763.

Bоотн, R. G.; Cox, M. L. \& MADGe, R. B. 1990. IIe guides to insects of importance to man. 3. Coleoptera. International Institute of Entomology. London, The Natural History Museum. 384 p.

Borowiec, L. 1995. Tribal classification of the cassidoid Hispinae (Coleoptera: Chrysomelidae). In: PakAluk, J. \& Ślipiński, S. A. eds. Biology, phylogeny, and classification of Coleoptera. Warszawa, Muzeum i Instytut Zoologii PAN. v. 1, p.541-558.

1996. Faunistic records of Neotropical Cassidinae (Coleoptera: Chrysomelidae). Polsk. Pismo Entom., Wroclaw, 165:119-251.

Buzzi, Z. J. 1999. Uma nova espécie de Euctenochira Hincks (Coleoptera, Chrysomelidae, Cassidinae), da Serra do Japi, Jundiaí, São Paulo, Brasil. Revta bras. Zool., Curitiba, 16(3):771-773.

Chapuis, F. 1875. Histoire naturelle des insectes. Genera des coléoptères... Paris, Roret. v. 11,420 p.

Hincks, W. D. 1950. Some nomenclatorial notes on Chrysomelidae (Col.). Ann. Mag. nat. Hist., London, Serie 12, 3(1):506-512.

1952. The genera of the Cassidinae (Coleoptera: Chrysomelidae). Trans. R. ent. Soc. Lond., London, 103:327-358.

Lawrence, J. L. \& Newton, A. F. 1995. Families and subfamilies of Coleoptera (with selected genera, notes, references and data on family-group names). In: PAKALUK, J. \& ŚLIPIŃSKI, S. A. eds. Biology, phylogeny, and classification of Coleoptera. Warszawa, Muzeum i Instytut Zoologii PAN. v. 2, p.779-1006.

Rościszewska, M. 1980. The sense organs in larvae and imagines of Cassida viridis L. (Coleoptera, Chrysomelidae). Part I. Antennae. Acta biol. cracov., Ser. Zool., Cracovia, 22:191-198.

. 1981. The sense organs in larvae and imagines of Cassida viridis L. (Coleoptera, Chrysomelidae).

Part II. Mouth parts. Acta biol. cracov., Ser. Zool., Cracovia, 23:53-67.

Spaeth, F. 1926. Monographie der zur Grupe der Coptocyclitae gehörigen Amerikanischen Cassidinen

(Col.): I. Die Gattungen mit gekämmten Klauen. Suppl. Ent., Berlin, 13:1-108.

ŚwietojańsKa, J. \& Borowiec, L. 1999. Three new species of Microctenochira Spaeth from Brazil and Panama (Coleoptera: Chrysomelidae: Cassidinae). Genus, Wroclaw, 10(1):109-116.

Recebido em 04.06.2002; aceito em 28.08.2002 